\title{
Structural studies on the $O$-linked carbohydrate chains of human platelet glycocalicin
}

\author{
Sophia A. M. KORREL, Kenneth J. CLEMETSON, Herman VAN HALBEEK, Johannis P. KAMERLING, Jan J. SIXMA, \\ and Johannes F. G. VLIEGENTHART
}

Departments of Bio-Organic Chemistry and Haematology, University of Utrecht; and Theodor Kocher Institute, Bern

(Received December 6, 1983) - EJB 831298

Glycocalicin (140 kDa), constituting the main part of glycoprotein Ib $(160 \mathrm{kDa})$, was released from the human platelet membrane by the action of a $\mathrm{Ca}^{2+}$-dependent protease, present in the platelet cytoplasm and liberated during sonication of the platelet suspension. After activation of the protease by $\mathrm{Ca}^{2+}$, the sonicated plateled suspension was subjected to differential centrifugation. The supernatant was applied to a column of wheat germ agglutinin linked to Sepharose 4B; glycocalicin was eluted from the column with $2.5 \%$ (w/v) $N$-acetylglucosamine.

Glycocalicin was found to contain $40 \%$ carbohydrate by weight, representing $N$ - as well as $O$-glycosidically linked carbohydrate chains. The $O$-glycosidic chains were split off by alkaline cleavage in the presence of ${ }^{3} \mathrm{H}$-labelled $\mathrm{NaBH}_{4}$. The liberated ${ }^{3} \mathrm{H}$-labelled oligosaccharide-alditols were fractionated on a DEAE-Sephadex A-25 column. The structures of the oligosaccharide-alditols were investigated by $500-\mathrm{MHz}{ }^{1} \mathrm{H}-\mathrm{NMR}$ spectroscopy. The major compound was identified as $\operatorname{NeuAc} \alpha(2 \rightarrow 3) \mathrm{Gal} \beta(1 \rightarrow 3)[\mathrm{NeuAc} \alpha(2 \rightarrow 3) \mathrm{Gal} \beta(1 \rightarrow 4) \mathrm{GlcNAc} \beta(1 \rightarrow 6)] \mathrm{GalNAc}$-ol. Two minor compounds were found to be NeuAc $\alpha(2 \rightarrow 3) \mathrm{Gal} \beta(1 \rightarrow 3)[\mathrm{NeuAc} \alpha(2 \rightarrow 6)] \mathrm{GalNAc}-\mathrm{ol}$ and NeuAc $\alpha(2 \rightarrow 3)$ Gal $\beta(1 \rightarrow 3)$ GalNAc-ol.

Platelet membrane glycoproteins play functional roles in vital processes such as platelet aggregation and adhesion [1]. Glycoprotein Ib $(160 \mathrm{kDa})$ is one of the main membrane glycoproteins. By the action of a $\mathrm{Ca}^{2+}$-dependent protease, present in the platelet cytoplasm, glycocalicin $(140 \mathrm{kDa})$, constituting the main part of glycoprotein $\mathrm{Ib}[2,3]$, can be cleaved from the platelet surface [4]. Glycoprotein Ib/glycocalicin is probably the receptor for Von Willebrand's factor in the presence of ristocetin [5] and for platelet adhesion to the vessel wall [6]. The carbohydrate chains of glycoprotein $\mathrm{Ib}$ may be involved in the aforementioned interaction phenomena.

Glycocalicin was reported to have a carbohydrate content or $60 \%$ (w/w) comprising $N$ - as well as $O$-glycosidically linked carbohydrate chains [7-9]. The major $O$-linked carbohydrate chain, isolated by Judson et al. [8], was shown to be a hexasaccharide-alditol containing $N$-acetylneuraminic acid, galactose, $\mathrm{N}$-acetylglucosamine and $\mathrm{N}$-acetylgalactosaminitol in the molar ratio $2: 2: 1: 1$. Here we describe the elucidation, by $500-\mathrm{MHz}^{1} \mathrm{H}-\mathrm{NMR}$ spectroscopy, of the primary structures of the prevalent $O$-glycosidic carbohydrate chains of glycocalicin. A preliminary account of this study has been presented [10]. During the preparation of the manuscript of this paper a report by Tsuji et al. [9] appeared describing the structure of the main $O$-glycosidic chain, derived by methylation analysis in combination with enzymic degradation studies.

\section{MATERIALS AND METHODS}

\section{Isolation of glycocalicin from human platelets}

Platelets (40 units), obtained from the Central Laboratory of the Blood Transfusion Service of the Swiss Red Cross [2],

Abbreviations. SDS, sodium dodecyl sulfate; WGA, wheat germ agglutinin; NOE, nuclear Overhauser enhancement. were resuspended in $80 \mathrm{ml} 10 \mathrm{mM}$ Tris/ $\mathrm{HCl}$ buffer, $\mathrm{pH} 8.0$, containing $20 \mathrm{mM} \mathrm{CaCl}_{2}$. The suspension was cooled to $4{ }^{\circ} \mathrm{C}$ and sonicated for 2 min with a B-30 sonifier (Branson Sonic Power Company, Danbury, USA) (output control 7, 50\% duty cycle; pulsed mode). After incubating the suspension for $1 \mathrm{~h}$ at room temperature, it was subjected to differential centrifugation $(9000 \times \mathrm{g}$ for $20 \mathrm{~min}$ followed by $100000 \times \mathrm{g}$ for $1 \mathrm{~h}, 4^{\circ} \mathrm{C}$ ). The supernatant was mixed with EDTA ( $4 \mathrm{mM}$ final concentration) and sodium deoxycholate $(0.5 \%$ final concentration) and subsequently applied to a $50 \mathrm{ml}$ WGASepharose 4B column [11] equilibrated with $10 \mathrm{mM}$ Tris/HCl buffer, $\mathrm{pH} 8.0$, containing $0.5 \%(\mathrm{w} / \mathrm{v})$ sodium deoxycholate. The column was washed with the same buffer until the flowthrough peak had eluted and the absorbance of the effluent at $280 \mathrm{~nm}$ had returned to the base line; then the column was washed with $50 \mathrm{ml}$ buffer without deoxycholate. Glycocalicin was eluted with $2.5 \%(\mathrm{w} / \mathrm{v}) \mathrm{N}$-acetylglucosamine in $10 \mathrm{mM}$ Tris/ $\mathrm{HCl}$ buffer, $\mathrm{pH} 8.0$. dialyzed against water and lyophilized. The purity was checked by SDS/polyacrylamide gel electrophoresis [12].

\section{Alkaline borohydride treatment}

Glycocalicin $(10 \mathrm{mg})$ was treated with $4 \mathrm{ml} 0.1 \mathrm{M} \mathrm{NaOH}$ containing $148.5 \mathrm{mg} \mathrm{NaBH}$ and $2.7 \mathrm{mg}{ }^{3} \mathrm{H}$-labelled $\mathrm{NaBH}_{4}$ (spec. act. $12.9 \mathrm{GBq} / \mathrm{mmol}$; New England Nuclear, USA), final activity $925 \mathrm{MBq}$. After $20 \mathrm{~h}$ at $40^{\circ} \mathrm{C}$ the solution was acidified to $\mathrm{pH} 5.0$ with $4 \mathrm{M}$ acetic acid and applied to a column $(20 \times 2 \mathrm{~cm})$ of Dowex $50 \mathrm{WX} 8, \mathrm{H}^{+}$form $(100-200$ mesh). The column was washed with $180 \mathrm{ml}$ water and the eluate lyophilized. Boric acid was removed by co-evaporation with methanol under reduced pressure. The mixture of oligosaccharide-alditols obtained was subjected to preparative descending chromatography on Whatman 3MM paper for 
$24 \mathrm{~h}$ at room temperature using $n$-butanol/ethanol/water $(4: 1: 1, \mathrm{v} / \mathrm{v})$ as solvent system. The ${ }^{3} \mathrm{H}$-labelled material present at the origin was recovered from the paper with water.

\section{Fractionation of the oligosaccharide-alditols}

The lyophilized mixture of ${ }^{3} \mathrm{H}$-labelled oligosaccharidealditols $(14.8 \mathrm{kBq})$ was dissolved in $0.05 \mathrm{M}$ pyridine/acetate buffer, pH 5.0, and applied to a column $(60 \times 1.5 \mathrm{~cm})$ of DEAE-Sephadex A-25 (Pharmacia, Uppsala, Sweden), equilibrated with the same buffer. The column was eluted with $400 \mathrm{ml}$ of a linear concentration gradient of $0.05-1.0 \mathrm{M}$ pyridine/acetate buffer, pH 5.0 [13]. Fractions of $4 \mathrm{ml}$ were collected at a flow rate of $24 \mathrm{ml} / \mathrm{h}$ and assayed for radioactivity. ${ }^{3} \mathrm{H}$-labelled peaks were pooled, lyophilized and desalted on a column $(90 \times 2.5 \mathrm{~cm})$ of Bio-Gel P-6 (Bio-Rad, Richmond, USA) using water as eluent at a flow rate of $20 \mathrm{ml} / \mathrm{h}$.

\section{Analytical methods}

SDS/polyacrylamide gel electrophoresis was performed in $8 \%$ polyacrylamide gels according to Laemmli [12]. The gels were stained with the periodic acid/Schiff reagent [14] or by using the silver nitrate staining method of Morrisey [15].

Sugar analysis was carried out by gas-liquid chromatography on a CPsil5 WCOT fused silica capillary column $(25 \mathrm{~m}$ $\times 0.32 \mathrm{~mm}$ i.d.) using a Varian Aerograph 3700 gas chromatograph. The trimethylsilylated methyl glycosides were prepared by methanolysis, $N$-(re)acetylation and trimethylsilylation $[16,17]$.

Prior to ${ }^{1} \mathrm{H}-\mathrm{NMR}$ spectroscopic analysis the desalted samples were repeatedly treated with ${ }^{2} \mathrm{H}_{2} \mathrm{O}(99.996$ atom \% ${ }^{2} \mathrm{H}$, Aldrich, Milwaukee, USA) at $\mathrm{p}^{2} \mathrm{H} 7$ and room temperature. $500-\mathrm{MHz}{ }^{1} \mathrm{H}-\mathrm{NMR}$ spectra were recorded using a Bruker WM-500 spectrometer (SON hf-NMR facility, Department of Biophysical Chemistry, University of Nijmegen, The Netherlands) operating in the pulsed Fourier-transform mode at a probe temperature of $27^{\circ} \mathrm{C}[18,19]$. Resolution enhancement of the spectra was achieved by Lorentzian-toGaussian transformation [20]. Chemical shifts $(\delta)$ are expressed in ppm downfield from internal sodium 4,4-dimethyl4-silapentane-1-sulfonate, but were actually measured by reference to internal acetone $\left(\delta=2.225 \mathrm{ppm}\right.$ in ${ }^{2} \mathrm{H}_{2} \mathrm{O}$ at $\left.27^{\circ} \mathrm{C}\right)$.

\section{RESULTS AND DISCUSSION}

\section{Preparation of glycocalicin}

Washed human platelets were resuspended in $10 \mathrm{mM}$ Tris/ $\mathrm{HCl}$ buffer, $\mathrm{pH} 8.0$, containing $20 \mathrm{mM} \mathrm{CaCl}$, and sonicated. During sonication the platelets were disrupted and the $\mathrm{Ca}^{2+}$-dependent protease, present in the cytoplasm, was released and activated by $\mathrm{Ca}^{2+}$. After an hour the suspension was subjected to differential centrifugation. To the final supernatant EDTA and sodium deoxycholate were added and the solution was then applied to a WGA-Sepharose 4B column. After desorption by $2.5 \% \mathrm{~N}$-acetylglucosamine the fractions containing glycocalicin were pooled, dialyzed against water and lyophilized. The purity of this glycocalicin fraction was checked by SDS/polyacrylamide gel electrophoresis. Upon staining with the periodic acid/Schiff and silver nitrate reagents, the gels showed only one band (see Fig. 1).

Sugar analysis of the glycocalicin preparation indicated the presence of Gal, GlcNAc, GalNAc, NeuAc, Man and Fuc.
A B

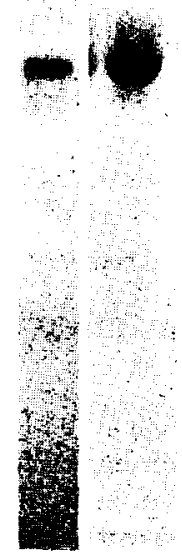

Fig. 1. SDS/polyacrylamide gels of glycocalicin after affinity chromatography on $W G A$-Sepharose $4 B$. Lane A, silver-nitrate-stained gel [15]; lane B, periodic acid/Schiff-stained gel [14]

Table 1. Carbohydrate content and molar composition of glycocalicin and its carbohydrate chains released by alkaline borohydride reduction The molar ratios for the intact glycoprotein were calculated relative to $1 \mathrm{~mol} \mathrm{GalNAc}$; those for the mixture obtained after alkaline borohydride reduction, relative to $1 \mathrm{~mol}$ GalNAc-ol

\begin{tabular}{llll}
\hline $\begin{array}{l}\text { Mono- } \\
\text { saccharide }\end{array}$ & \multicolumn{2}{l}{ Molar ratio in glycocalicin } \\
\cline { 2 - 4 } & $\begin{array}{l}\text { present } \\
\text { study }\end{array}$ & $\begin{array}{l}\text { Okumura } \\
\text { et al. [7] }\end{array}$ & $\begin{array}{l}\text { after alkaline boro- } \\
\text { hydride reduction }\end{array}$ \\
\hline Fuc & 0.4 & 0.3 & 0.2 \\
Man & 0.7 & 0.2 & 0.9 \\
Gal & 2.4 & 2.6 & 3.4 \\
GalNAc & 1 & 1 & - \\
GalNAc-ol & - & - & 1 \\
GcNAc & $6.3(1.4)^{\mathrm{a}}$ & 1.2 & 2.2 \\
GlcNAc-ol & - & - & 2.3 \\
NeuAc & 2.0 & 2.1 & 3.0 \\
\hline & $\%(\mathrm{w} / \mathrm{w})$ & & \\
Carbohydrate & & & \\
content & 40 & 60 &
\end{tabular}

a The GlcNAc content of this preparation is high because of incomplete removal of GlcNAc from the WGA-Sepharose column procedure. After prolonged dialysis the GlcNAc content is 1.4

Molar ratios are presented in Table 1 together with the data published by Okumura et al. [7]. As is evident from the table the sugar composition of both preparations are very similar but the mannose content of the preparation described here is significantly higher and the total carbohydrate content is somewhat lower $(40 \% \mathrm{w} / \mathrm{w})$. The difference in carbohydrate content may point to a difference in length of the isolated polypeptide chain.

\section{Isolation and characterization of oligosaccharide-alditols}

Alkaline borohydride reductive treatment of glycocalicin resulted in a mixture of ${ }^{3} \mathrm{H}$-labelled oligosaccharide-alditols. 


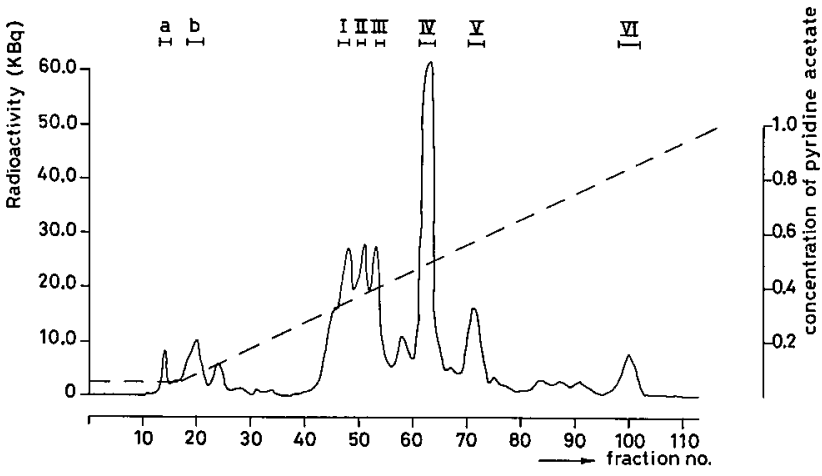

Fig. 2. Fractionation pattern of the ${ }^{3} \mathrm{H}$-labelled oligosaccharide-alditols derived from glycocalicin on DEAE-Sephadex $A-25(60 \times 1.5 \mathrm{~cm})$. The column was eluted with a linear concentration gradient (---) of $0.05-1.0 \mathrm{M}$ pyridine/acetate buffer, $\mathrm{pH} 5.0$. Fractions of $4 \mathrm{ml}$ were collected at a flow rate of $24 \mathrm{ml} / \mathrm{h}$ and assayed for ${ }^{3} \mathrm{H}$ radioactivity. Based on activity counting, $100 \%$ recovery was recorded. Fractions vere pooled according to the bars

Table 2. Carbohydrate content and molar composition of the desalted oligosaccharide-alditol fractions $I-V I$ of the DEAE-Sephadex A-25 column

The molar ratios are calculated relative to $1 \mathrm{~mol}$ GalNAc-ol

\begin{tabular}{|c|c|c|c|c|c|c|}
\hline \multirow{2}{*}{$\begin{array}{l}\text { Mono- } \\
\text { saccharide }\end{array}$} & \multicolumn{6}{|c|}{ Molar ratio in fraction } \\
\hline & I & II & III & IV & $\mathrm{V}$ & VI \\
\hline Man & 3.8 & 6.7 & 1.5 & 0.2 & 0.5 & 0.5 \\
\hline Gal & 10.4 & 14.0 & 3.6 & 2.3 & 1.8 & 3.4 \\
\hline $\mathrm{Glc}^{\mathrm{a}}$ & 2.8 & 4.5 & 1.3 & + & 0.7 & 1.2 \\
\hline GlcNAc & 3.5 & 12.0 & 1.4 & 1.2 & 0.4 & 1.4 \\
\hline GalNAc-ol & 1 & 1 & 1 & 1 & 1 & 1 \\
\hline \multirow[t]{2}{*}{ NeuAc } & 2.6 & 10.0 & 1.6 & 1.9 & 2.1 & 2.2 \\
\hline & \multicolumn{6}{|l|}{ nmol } \\
\hline GalNAc-ol & 8 & 3 & 21 & 128 & 29 & 11 \\
\hline
\end{tabular}

a Glucose material present in the fractions is probably derived from "he DEAE-Sephadex A-25 column material

The carbohydrate composition of this mixture (see Table 1) shows that, besides GalNAc-ol, GlcNAc-ol appeared in the sugar analysis, which stems for the greater part from the incomplete removal of $\mathrm{N}$-acetylglucosamine used in the affinity column procedure. The occurrence of Man besides GalNAc-ol suggests that $N$-glycosidic carbohydrate chains have also been released.

In Fig. 2 the fractionation pattern of the oligosaccharidealditols on DEAE-Sephadex A-25 has been depicted. The carbohydrate compositions of fractions I - VI, obtained after desalting on Bio-Gel P-6, are given as molar ratios in Table 2. The total amount of $O$-glycosidic alditols in fractions $\mathrm{I}-\mathrm{VI}$ is expressed as the molar amount of GalNAc-ol. It should be mentioned that radioactivity may lead to an overestimation of these amounts, due to aspecific ${ }^{3} \mathrm{H}$-labelling of material different from oligosaccharide-alditols (compare Fig. 2). The two rapidly eluting peaks, $a$ and $b$, in the neutral region, contained mainly GlcNAc-ol but no GalNAc-ol as was evident from sugar analysis. This implies that no asialo $O$-glycosidic carbohydrate chains occur in the cleavage product of glycocalicin.
Fractions I - VI, as well as the mixture of oligosaccharidealditols, were subjected to $500-\mathrm{MHz}{ }^{1} \mathrm{H}-\mathrm{NMR}$ spectroscopy. The spectra of the mixture and the major fraction IV are depicted in Fig. 3 and 4, respectively. The chemical shifts of the structural-reporter groups of the constituting monosaccharides of fractions III, IV and V, together with those of some reference oligosaccharide-alditols [21,22], are listed in Table 3.

The spectrum of fraction IV (Fig. 4) shows that this sample contains a highly pure oligosaccharide-alditol with a mucin-type structure ending in a 3,6-disubstituted GalNAc-ol residue. The chemical shift of $\mathrm{H}-2$ of GalNAc-ol $(\delta=4.387 \mathrm{ppm})$ indicates the presence of $\mathrm{Gal}$ in $\beta(1 \rightarrow 3)$-linkage to GalNAc-ol [22]. The set of H-5 and H-6 chemical shifts of GalNAc-ol $(\delta \mathrm{H}-5=4.265 \mathrm{ppm}$ and $\delta \mathrm{H}-6=3.928 \mathrm{ppm})$ points to the presence of GlcNAc $\beta(1 \rightarrow 6)$-linked to GalNAc-ol $[21,22]$. Based on the carbohydrate composition of fraction IV (Table 2), the occurrence of three $\mathrm{H}-1$ doublets at $\delta \approx 4.54 \mathrm{ppm}$ having $J_{1,2} \approx 8.0 \mathrm{~Hz}$ indicates that a second $\mathrm{Gal}$ residue is present in $\beta$-linkage. This $\mathrm{Gal}$ residue is $\beta(1 \rightarrow 4)$-linked to GIcNAc because of the presence of the GlcNAc H-6 signal at $\delta=4.004 \mathrm{ppm}$. Such a value points to a Gal $\beta(1 \rightarrow 4) \mathrm{GlcNAc}$ $\beta(1 \rightarrow \cdot)$ moiety (cf. $[21,22]$ ).

Both Gal residues are substituted by NeuAc in $\alpha(2 \rightarrow 3)$ linkage. This is evident from the presence of two coinciding NeuAc H-3ax triplets, at $\delta=1.800 \mathrm{ppm}$, and of two H-3eq signals of equal intensity, at $\delta=2.755 \mathrm{ppm}$ and $\delta=2.775 \mathrm{ppm}$ [18]. Further evidence for these structural elements stems from the resonance positions of the Gal $\mathrm{H}-1$ signals, since they are both shifted downfield as compared to D (see Table 3). This fits the empirical chemical shift rules for $\alpha(2 \rightarrow 3)$ sialylation of $N$-acetyllactosamine branches in $N$-glycosidic glycopeptides $[18,19]$. Moreover, the Gal $\mathrm{H}-3$ signals coincide at $\delta=4.113 \mathrm{ppm}$. Therefore, the structure of the main oligosaccharide-alditol IV has been identified as:

$$
\begin{array}{r}
\operatorname{NeuAc} \alpha(2 \rightarrow 3) \mathrm{Gal} \beta(1 \rightarrow 3) \\
\operatorname{NeuAc} \alpha(2 \rightarrow 3) \mathrm{Gal} \beta(1 \rightarrow 4) \mathrm{GlcNAc} \beta(1 \rightarrow 6)
\end{array}>\text { GalNAc-ol }
$$

The assignment of the three doublets at $\delta \approx 4.54 \mathrm{ppm}$ could not be obtained on the basis of their chemical shifts and coupling constants, only. However, the 1,3-diaxial relation between $\mathrm{H}-1$ and $\mathrm{H}-3$ of $\beta$-linked Gal allows to identify the Gal anomeric protons by means of an NOE effect upon presaturation of the $\mathrm{H}-3$ signals, at $\delta=4.113 \mathrm{ppm}$. The doublets at $\delta=4.529 \mathrm{ppm}\left(J_{1,2}=8.1 \mathrm{~Hz}\right)$ and $\delta=4.545 \mathrm{ppm}$ $\left(J_{1,2}=8.4 \mathrm{~Hz}\right)$ showed an NOE effect. In consequence, the $\mathrm{H}-1$ doublet at $\delta=4.550 \mathrm{ppm}\left(J_{1.2}=8.3 \mathrm{~Hz}\right)$ belongs to GlcNAc. The $\mathrm{Gal}^{3}$ and $\mathrm{Gal}^{4} \mathrm{H}-1$ signals could be distinguished from each other by comparison of their shifts with those of the monosialo analogue $\mathrm{E}$ (see Table 3 ).

The assignment of the $\mathrm{H}-3 e q$ signal at $\delta=2.775 \mathrm{ppm}$ to $\mathrm{NeuAc}^{3.3}$ is based on the data for the reference compounds $\mathrm{B}, \mathrm{C}$ and $\mathrm{E}$ (see Table 3 ). Thus the $\mathrm{H}-3 e q$ signal at $\delta=2.755 \mathrm{ppm}$ belongs to $\mathrm{NeuAc}^{3,4}$, a value frequently observed for NeuAc $\alpha(2 \rightarrow 3) \mathrm{Gal} \beta(1 \rightarrow 4) \mathrm{GlcNAc} \beta(1 \rightarrow \cdot)$ elements in $N$-glycosidic chains $[18,19]$. A similar reasoning applies to the $N$-acetyl signals at $\delta=2.033 \mathrm{ppm}\left(\mathrm{NeuAc}^{3,3}\right)$ and at $\delta=2.031 \mathrm{ppm}\left(\mathrm{NeuAc}^{3,4}\right)$. Attachment of NeuAc in $\alpha(2 \rightarrow 3)$-linkage to $N$-acetyllactosamine is expected to give rise to a well-known effect on the position of the $N$-acetyl signal of GlcNAc $(\Delta \delta=-0.003 \mathrm{ppm})$ (compare [19]). For this reason the singlet at $\delta=2.062 \mathrm{ppm}$ is assigned to GlcNAc.

The main peaks in the spectrum of fraction $\mathrm{V}$ are superimposable with those of reference compound $C$ (see 


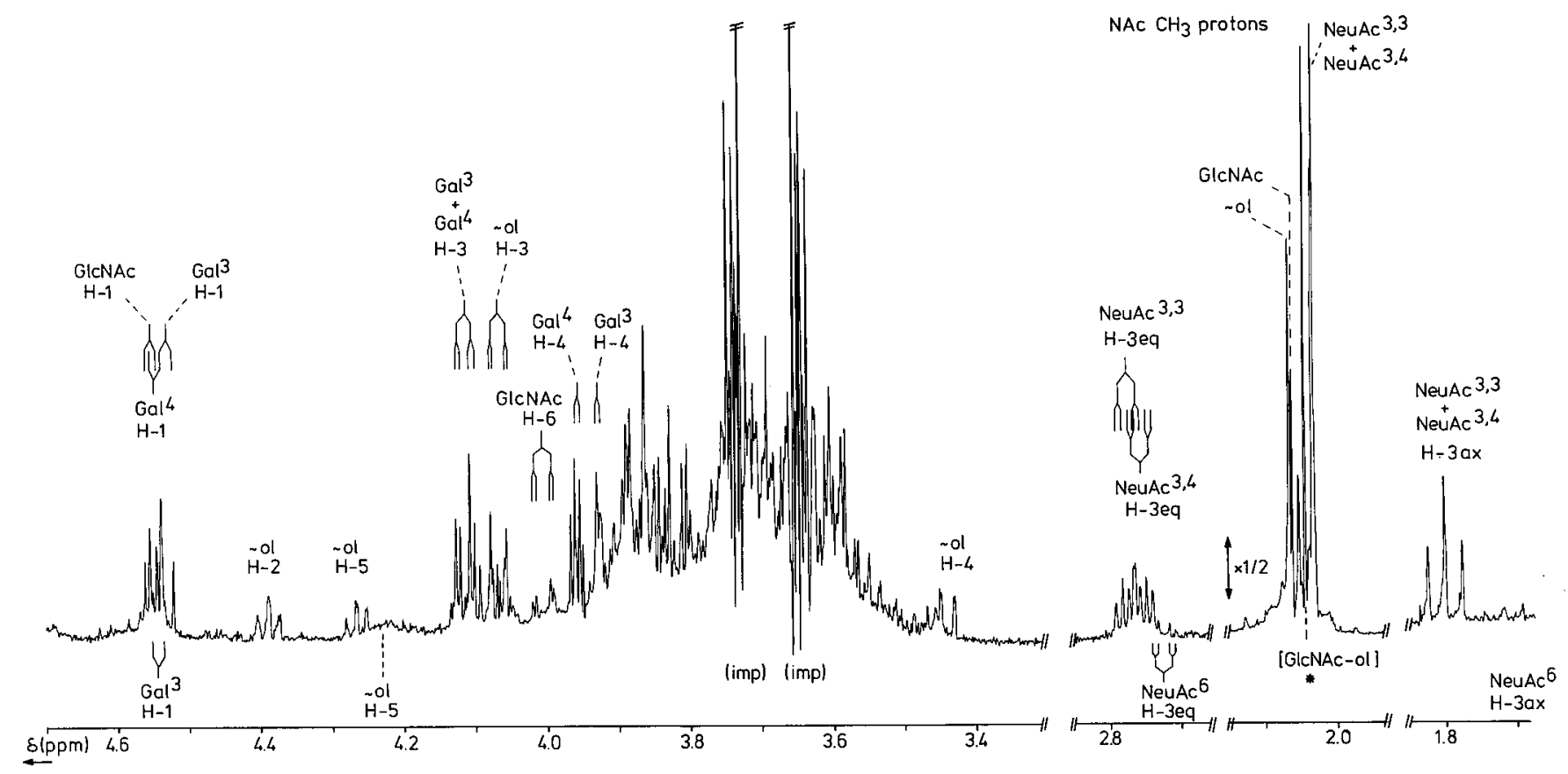

Fig. 3. 500-MHz ${ }^{1} \mathrm{H}-\mathrm{NMR}$ spectrum, recorded in ${ }^{2} \mathrm{H}_{2} \mathrm{O}$ at $\mathrm{p}^{2} \mathrm{H} 7$ and $27^{\circ} \mathrm{C}$, of the mixture of oligosaccharide-alditols obtained after alkaline borohydride treatment of glycocalicin

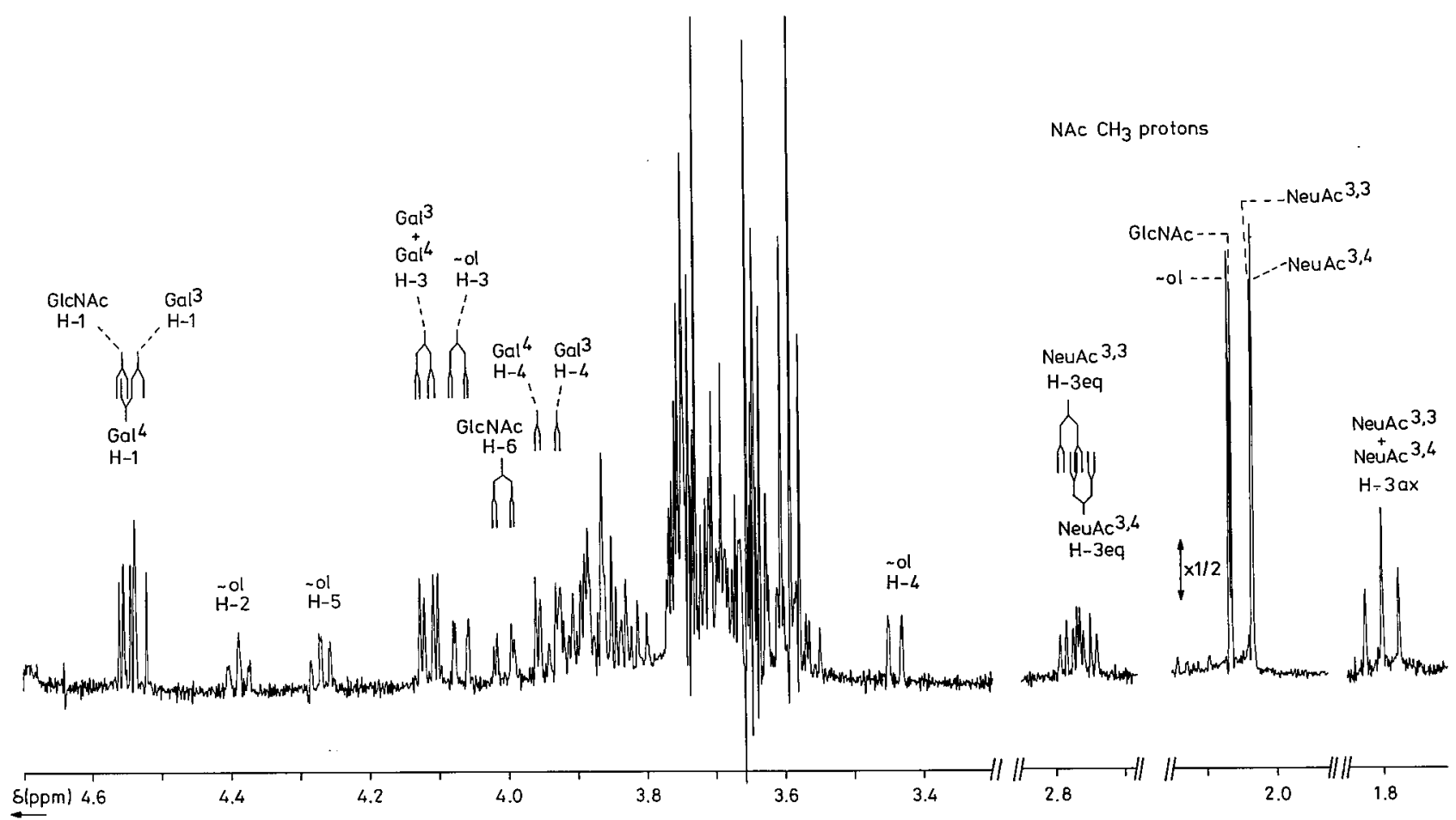

Fig. 4. 500-MHz ${ }^{1} \mathrm{H}-\mathrm{NMR}$ spectrum, recorded in ${ }^{2} \mathrm{H}_{2} \mathrm{O}$ at $p^{2} \mathrm{H} 7$ and $27^{\circ} \mathrm{C}$, of the purified hexasaccharide-alditol, fraction $\mathrm{IV}$, from glycocalicin

Table 3). The following characteristic features may be mentioned. Two sets of NeuAc H-3ax and $\mathrm{H}-3 e q$ signals with equally high intensity are observed. One of them $(\delta \mathrm{H}-$ $3 a x=1.799 \mathrm{ppm}, \delta \mathrm{H}-3 e q=2.773 \mathrm{ppm})$ is specific for Neu$\mathrm{Ac} \alpha(2 \rightarrow 3)$-linked to $\mathrm{Gal}^{3}$. The other $(\delta \mathrm{H}-3 a x=1.692 \mathrm{ppm}$, $\delta \mathrm{H}-3 e q=2.725 \mathrm{ppm})$ is indicative of NeuAc $\alpha(2 \rightarrow 6)$-linked to GalNAc-ol $[18,21]$. The spectrum shows in the $N$-acetyl proton region two signals in the intensity ratio of $1: 2$. The singlet at $\delta=2.041 \mathrm{ppm}$ is assigned to GalNAc-ol and that at $\delta$ $=2.031 \mathrm{ppm}$ belongs to the NeuAc residues. This led to the 
Table 3. ${ }^{1} \mathrm{H}$ Chemical shifts of structural reporter group protons of constituent monosaccharides of the fractions III, IV and $V$ obtained from glycocalicin together with those of reference oligosaccharide-alditols $A-E[21,22]$

The first superscript at the name of a sugar residue indicates to which position of the adjacent monosaccharide it is glycosidically linked. A second superscript is used to discriminate between identically linked residues, by indicating the type of the next linkage in the sequence. Chemical shifts are in ppm downfield from internal 4,4-dimethyl-4-silapentane-1-sulfonate in ${ }^{2} \mathrm{H}_{2} \mathrm{O}$ at $27^{\circ} \mathrm{C}$ acquired at $500 \mathrm{MHz}$. In the table heading structures are represented by short-hand symbolic notation (cf. $[19,22]): \diamond=$ GalNAc-ol; $\mathbf{-}-=\mathrm{Gal} ; \bullet-\mathrm{GlcNAc} ; \Delta-=\mathrm{NeuAc} \alpha(2 \rightarrow 3)$ and $0-=\operatorname{NeuAc} \alpha(2 \rightarrow 6)$. n.d. $=$ not determined

\begin{tabular}{|c|c|c|c|c|c|c|c|c|c|}
\hline \multirow[t]{3}{*}{ Residue } & \multirow{3}{*}{$\begin{array}{l}\text { Reporter } \\
\text { group }\end{array}$} & \multicolumn{8}{|c|}{ Chemical shift in compound } \\
\hline & & A & B & III & $\mathrm{C}$ & $\mathrm{V}$ & $\mathrm{D}$ & E & IV \\
\hline & & \multicolumn{8}{|l|}{ ppm } \\
\hline GalNAc-ol & $\begin{array}{l}\text { H-2 } \\
\text { H-3 } \\
\text { H-4 } \\
\text { H-5 } \\
\text { H-6 } \\
\text { H-6 } \\
\text { NAc }\end{array}$ & $\begin{array}{l}4.395 \\
4.065 \\
3.507 \\
4.196 \\
3.69 \\
3.628 \\
2.050\end{array}$ & $\begin{array}{l}4.390 \\
4.074 \\
3.498 \\
4.187 \\
3.68 \\
3.65 \\
2.046\end{array}$ & $\begin{array}{l}4.387 \\
4.072 \\
3.500 \\
4.198 \\
\text { n.d. } \\
\text { n.d. } \\
2.045\end{array}$ & $\begin{array}{l}4.378 \\
4.067 \\
3.524 \\
4.240 \\
3.84 \\
3.475 \\
2.042\end{array}$ & $\begin{array}{l}4.378 \\
4.067 \\
\text { n.d. } \\
4.232 \\
\text { n.d. } \\
3.471 \\
2.041\end{array}$ & $\begin{array}{l}4.394 \\
4.060 \\
3.465 \\
4.282 \\
3.931 \\
3.7 \\
2.067\end{array}$ & $\begin{array}{l}4.390 \\
4.072 \\
3.456 \\
4.272 \\
3.927 \\
3.7 \\
2.066\end{array}$ & $\begin{array}{l}4.387 \\
4.066 \\
3.441 \\
4.265 \\
3.928 \\
\text { n.d. } \\
2.065\end{array}$ \\
\hline $\mathrm{Gal}^{3}$ & $\begin{array}{l}\mathrm{H}-1 \\
\mathrm{H}-3 \\
\mathrm{H}-4\end{array}$ & $\begin{array}{l}4.478 \\
3.671 \\
3.901\end{array}$ & $\begin{array}{l}4.547 \\
4.122 \\
3.931\end{array}$ & $\begin{array}{l}4.545 \\
4.123 \\
3.927\end{array}$ & $\begin{array}{l}4.541 \\
4.117 \\
3.927\end{array}$ & $\begin{array}{l}4.541 \\
4.105 \\
3.925\end{array}$ & $\begin{array}{l}4.465 \\
3.66 \\
3.900\end{array}$ & $\begin{array}{l}4.534 \\
4.116 \\
3.922\end{array}$ & $\begin{array}{l}4.529 \\
4.113 \\
3.928\end{array}$ \\
\hline GlcNAc & $\begin{array}{l}\mathrm{H}-1 \\
\mathrm{H}-6 \\
\text { NAc }\end{array}$ & $\begin{array}{l}- \\
- \\
-\end{array}$ & $\begin{array}{l}- \\
- \\
-\end{array}$ & $\begin{array}{l}- \\
-\end{array}$ & $\begin{array}{l}- \\
- \\
-\end{array}$ & $\begin{array}{l}- \\
- \\
-\end{array}$ & $\begin{array}{l}4.560 \\
3.998 \\
2.064\end{array}$ & $\begin{array}{l}4.559 \\
3.993 \\
2.066\end{array}$ & $\begin{array}{l}4.550 \\
4.004 \\
2.062\end{array}$ \\
\hline $\mathrm{Gal}^{4}$ & $\begin{array}{l}\mathrm{H}-1 \\
\mathrm{H}-3 \\
\mathrm{H}-4\end{array}$ & $\begin{array}{l}- \\
-\end{array}$ & $\begin{array}{l}- \\
-\end{array}$ & $\begin{array}{l}- \\
- \\
-\end{array}$ & $\begin{array}{l}- \\
- \\
-\end{array}$ & $\begin{array}{l}- \\
- \\
-\end{array}$ & $\begin{array}{l}4.470 \\
3.68 \\
3.925\end{array}$ & $\begin{array}{l}4.470 \\
3.7 \\
3.931\end{array}$ & $\begin{array}{l}4.545 \\
4.113 \\
3.956\end{array}$ \\
\hline $\mathrm{NeuAc}^{3,3}$ & $\begin{array}{l}\text { H-3ax } \\
\text { H-3eq } \\
\text { NAc }\end{array}$ & $\begin{array}{l}- \\
- \\
-\end{array}$ & $\begin{array}{l}1.800 \\
2.774 \\
2.034\end{array}$ & $\begin{array}{l}1.800 \\
2.771 \\
2.033\end{array}$ & $\begin{array}{l}1.800 \\
2.774 \\
2.032\end{array}$ & $\begin{array}{l}1.799 \\
2.773 \\
2.031\end{array}$ & $\begin{array}{l}- \\
- \\
-\end{array}$ & $\begin{array}{l}1.801 \\
2.774 \\
2.033\end{array}$ & $\begin{array}{l}1.800 \\
2.775 \\
2.033\end{array}$ \\
\hline $\mathrm{NeuAc}^{6}$ & $\begin{array}{l}\text { H-3ax } \\
\text { H-3eq } \\
\text { NAc }\end{array}$ & $\begin{array}{l}- \\
- \\
-\end{array}$ & $\begin{array}{l}- \\
- \\
-\end{array}$ & $\begin{array}{l}- \\
- \\
-\end{array}$ & $\begin{array}{l}1.692 \\
2.723 \\
2.032\end{array}$ & $\begin{array}{l}1.692 \\
2.725 \\
2.031\end{array}$ & $\begin{array}{l}- \\
- \\
-\end{array}$ & $\begin{array}{l}- \\
- \\
-\end{array}$ & $\begin{array}{l}- \\
- \\
-\end{array}$ \\
\hline NeuAc ${ }^{3,4}$ & $\begin{array}{l}\text { H-3ax } \\
\text { H-3eq } \\
\text { NAc }\end{array}$ & $\begin{array}{l}- \\
\overline{-}\end{array}$ & $\begin{array}{l}- \\
- \\
-\end{array}$ & $\begin{array}{l}- \\
- \\
-\end{array}$ & $\begin{array}{l}- \\
- \\
-\end{array}$ & $\begin{array}{l}- \\
- \\
-\end{array}$ & $\begin{array}{l}- \\
- \\
-\end{array}$ & $\begin{array}{l}- \\
- \\
-\end{array}$ & $\begin{array}{l}1.800 \\
2.755 \\
2.031\end{array}$ \\
\hline
\end{tabular}

conclusion that fraction $\mathrm{V}$ contains the tetrasaccharidealditol:

$$
\begin{aligned}
\operatorname{NeuAc} \alpha(2 \rightarrow 3) \mathrm{Gal} \beta(1 \rightarrow 3) & >\text { GalNAc-ol } \\
\operatorname{NeuAc} \alpha(2 \rightarrow 6) & >\text { Gal }
\end{aligned}
$$

Although sugar analysis (Table 2) shows the presence of additional carbohydrate material in fraction $\mathrm{V}$, this could not be recognized in the NMR spectrum.

The spectrum of fraction III matches that of the linear trisaccharide-alditol B (see Table 3). Therefore it can be concluded that fraction III contains a constituent with the structure NeuAc $\alpha(2 \rightarrow 3) \mathrm{Gal} \beta(1 \rightarrow 3)$ GalNAc-ol. Sugar analysis (Table 2) suggests the additional presence of $N$-type carbohydrates which could not be deduced from the spectrum.

The spectra of fractions I, II and VI show no signals arising from other structural elements than those present in fractions III, IV and V. Signals stemming from $N$-glycosidic chains could not be detected in the spectra of fractions I, II and VI, although the latter must contain a certain amount of $\mathrm{N}$ glycosidic carbohydrate chains (see Table 2).
The spectrum of the mixture of oligosaccharide-alditols (Fig. 3) contains all the signals, even the smaller ones, that were found in one or more of the spectra of fractions I - VI. This implies that recording a spectrum before fractionation may give relevant information about the composition of the mixture. This information can be useful for the fractionation strategy.

The authors thank Mr W. Schnippering (Bern) for technical assistance with the preparation of glycocalicin and Mr G. J. Gerwig (Utrecht) for skilful assistance with the sugar analyses. This investigation was supported by the Netherlands Foundation for Chemical Research (SON) with financial aid from the Netherlands Organization for the Advancement of Pure Research (ZWO) and by the Netherlands Foundation for Cancer Research (KWF, grant UUKCOC 83-13).

\section{REFERENCES}

1. Berndt, M. C. \& Phillips, D. R. (1981) in Research Monographs in Cell and Tissue Physiology, vol. 5 (Dingle, J. T. \& Gordon, J. L., 
eds) pp. 43-75, Elsevier/North Holland Biomedical Press, Amsterdam.

2. Clemetson, K. J., Naim, H. Y. \& Lüscher, E. F. (1981) Proc. Natl Acad. Sci. USA 78, 2712-2716.

3. Solum, N. O., Hagen, I. \& Slettbakk, T. (1980) Thromb. Res. 18, $773-785$.

4. Phillips, D. R. \& Jakábová, M. (1977) J. Biol. Chem. 252, $5602-5605$.

5. Ali-Briggs, E. F., Clemetson, K. J. \& Jenkins, C. S. P. (1981) Br.J. Haematol. 48, 305-318.

6. Weiss, H. J., Tschopp, T. B., Baumgartner, H. R., Sussman, I. I., Johnson, M. M. \& Egan, J. J. (1974) Am. J. Med. 57, 920-925.

7. Okumura, T., Lombart, C. \& Jamieson, G. A. (1976) J. Biol. Chem. 251, 5950-5955.

8. Judson, P. A., Anstee, D. J. \& Clamp, J. R. (1982) Biochem. J. 205, $81-90$.

9. Tsuji, T., Tsunehisa, S., Watanabe, Y., Yamamoto, K., Tohyama, H. \& Osawa, T. (1983) J. Biol. Chem. 258, 6335-6339.

10. Korrel, S. A. M., Clemetson, K. J., Van Halbeek, H., Kamerling, J. P., Sixma, J. J. \& Vliegenthart, J. F. G. (1983) in Proc. 7th Int. Symp. Glycoconjugates (Chester, M. A., Heinegård, D., Lundblad, A. \& Svensson, S., eds) pp. 186-187, Rahms i Lund, Sweden.
11. Clemetson, K. J., Pfueller, S. L., Lüscher, E. F. \& Jenkins, C. S. P. (1977) Biochim. Biophys. Acta 464, 493-508.

12. Laemmli, U. K. (1970) Nature (Lond.) 227, 680-685.

13. Saito, T., Itoh, T., Adachi, S., Suzuki, T. \& Usui, T. (1982) Biochim. Biophys. Acta 719, $309-317$.

14. Kapitany, R. A. \& Zebrowski, E. J. (1973) Anal. Biochem. 56, $361-369$.

15. Morrisey, J. H. (1981) Anal. Biochem. 117, 307-310.

16. Kamerling, J. P., Gerwig, G. J., Vliegenthart, J. F. G. \& Clamp, J. R. (1975) Biochem. J. 151, $491-495$.

17. Kamerling, J. P. \& Vliegenthart, J. F. G. (1982) Cell Biol. Monogr. $10,97-99$.

18. Vliegenthart, J. F. G., Van Halbeek, H. \& Dorland, L. (1981) Pure Appl. Chem. 53, 45-77.

19. Vliegenthart, J. F. G., Dorland, L. \& Van Halbeek, H. (1983) Adv. Carb. Chem. Biochem. 41, 209-374.

20. Ernst, R. R. (1966) Adv. Magn. Res. 2, $1-135$

21. Van Halbeek, H., Dorland, L., Vliegenthart, J. F. G., Fiat, A.-M. \& Jollès, P. (1981) FEBS Lett. 133, 45 - 50.

22. Van Halbeek, H., Dorland, L., Vliegenthart, J. F. G.; Hull, W. E., Lamblin, G., Lhermitte, M., Boersma, A. \& Roussel, P. (1982) Eur. J. Biochem. 127, 7-20.

S. A. M. Korrel, H. van Halbeek, J. P. Kamerling, and J. F. G. Vliegenthart, Afdeling Bio-Organische Chemie, Organisch-Chemisch Laboratorium, Rijksuniversiteit te Utrecht, Croesestraat 79, NL-3522-AD Utrecht, The Netherlands

K. J. Clemetson, Theodor Kocher Institut der Universität Bern, Freiestrasse 1, Postfach 99, CH-3000 Bern 9, Switzerland

J. J. Sixma, Afdeling Hematologie, Academisch Ziekenhuis, Catharijnesingel 101, NL-3500-GG Utrecht, The Netherlands 